\title{
Vascular flora of Jelenovac Forest Park (Zagreb, Croatia)
}

\author{
MARTA JUSTIĆ ${ }^{\star}$, MARIJA BUČAR ${ }^{2}$, PETRA VIZEC ${ }^{3}$, ANA VUKRES $^{4}$, VEDRAN ŠEGOTA \\ ${ }^{1}$ Garica 92, HR-51516 Vrbnik, Croatia \\ ${ }^{2}$ Vinogradska 46, HR-44250 Petrinja, Croatia \\ ${ }^{3}$ Vjekoslava Tkalca 44, HR-10382 Donja Zelina, Croatia \\ ${ }^{4}$ Donji Brvci 18, HR-48350 Đurđevac, Croatia \\ ${ }^{5}$ University of Zagreb, Faculty of Science, Department of Biology, ZA \& ZAHO herbaria collections, \\ Marulićev trg 20/II, HR-10000 Zagreb, Croatia
}

*Autor za dopisivanje / corresponding author: martaj133@gmail.com

Tip članka / article type: izvorni znanstveni članak / original scientific paper

Povijest članka / article history: primljeno / received: 11.05.2020., prihvaćeno / accepted: 18.06.2020.

URL: https://doi.org/10.46232/glashbod.8.2.1

Justić, M., Bučar, M., Vizec, P., Vukres, A., Šegota, V. (2020): Vascular flora of Park-forest

Jelenovac (Zagreb, Croatia). Glas. Hrvat. bot. druš. 8(2): 60-77.

\begin{abstract}
A floristic study of Jelenovac Forest Park, located in Zagreb city centre, was conducted during the vegetation season of 2019. In total, 255 vascular plant taxa were recorded, divided into 75 plant families, of which Compositae (12.55\%), Rosaceae (7.06\%) and Poaceae (6.67\%) are the most represented. The spectrum of life-forms indicates the dominance of hemicryptophytes (43.14\%) and phanerophytes (27.45\%). The chorological analysis shows a domination of Eurasian floral element (27.45\%), followed by large share of widespread (22.35\%) and cultivated and adventitious plants (18.04\%). Only one threatened, three strictly protected and as many as 12 invasive plant taxa were found. Comparison of flora of Jelenovac with similar urban and suburban areas of Zagreb conglomeration yielded diverse results, but still reflecting the common biogeographical position and influence of temperate climate and indicating a comparatively high anthropogenic influence.
\end{abstract}

Keywords: biodiversity, floral elements, life-forms, urban flora

Justić, M., Bučar, M., Vizec, P., Vukres, A., Šegota, V. (2020): Vaskularna flora Park šume Jelenovac (Zagreb, Hrvatska). Glas. Hrvat. bot. druš. 8(2): 60-77.

\section{Sažetak}

Florističko istraživanje Park šume Jelenovac u centru grada Zagreba provedeno je tijekom vegetacijske sezone 2019. Zabilježeno je ukupno 255 biljnih svojti podijeljenih u 75 biljnih porodica od kojih su Compositae (12,55 \%), Rosaceae (7,06 \%) i Poaceae (6,67 \%) najzastupljenije. Spektar životnih oblika ukazuje na dominaciju hemikriptofita $(43,14 \%)$ i fanerofita $(27,45 \%)$. Rezultati horološke analize ukazuju na 
dominaciju euroazijskog flornog elementa $(27,45 \%)$ iza kojeg slijedi visoki udio široko rasprostranjenih $(22,35 \%)$ te kultiviranih i adventivnih biljaka (18,04 \%). Zabilježena je samo jedna ugrožena, tri strogo zaštićene i čak 12 invazivnih svojti. Usporedba flore Jelenovca s drugim sličnim urbanim i suburbanim područjima zagrebačke konglomeracije ukazala je na određene razlike, ali ipak odražava zajedničku pripadnost istom biogeografskom području i utjecaj umjerene klime te ukazuje na razmjerno visok antropogeni utjecaj.

Ključne riječi: bioraznolikost, florni elementi, urbana flora, životni oblici

\section{Introduction}

Jelenovac Forest Park is situated on the southern slopes of Mt Medvednica at an elevation ranging from 150 to $260 \mathrm{~m}$ a. s. 1. (Anonymous 2020a). It is situated in the eastern part of the Zagreb city centre, only about ten minutes walk from the Zagreb main street Ilica (Fig. 1). It owes its name, which it shares with the associated forest stream, to the old village of the city serfs of the Vrhovec folnegia. The forest park includes a children's playground and numerous pathways running within and around the area, providing a large recreational space. The total area of the Park-forest is 54.5 ha, with the major part, 48.9 ha in area, covered with forests dominated by climazonal hornbeam and sessile oak forest (Ass. Epimedio-Carpinetum betuli (Horvat 1938) Bohridi 1963), while several grasslands and meadows are situated on higher altitudes in the northern part of the area (Anonymous 2020b).

According to Köppen's climatic types, the climate of the area of the city of Zagreb is temperate (Cfb) without a dry season and with a warm summer. The coldest month of the year is January with temperatures above $-3^{\circ} \mathrm{C}$, while the summers are fresh with the average temperature of the hottest month below $22^{\circ} \mathrm{C}$ (Šegota \& Filipčić 2003).

With the expansion of cities and population growth, the amount of urban areas is increasing. Urban areas are, unlike natural habitats, more affected by human activities that alter habitats, increase disturbance and the concentration of nitrogen in the soil and affect other biotic and abiotic factors, making them suitable for the growth of weeds, ruderal and invasive plants (Pyšek et al. 2010). Floristic studies of urban areas contribute to the understanding of the effects of urbanisation on flora composition and at the same time help preserve the biodiversity of such ecosystems. However, the plant diversity of urban areas in Croatia is considerably less studied than that of natural ecosystems. Comprehensive floristic data exist only for few Dalmatian cities: Šibenik and its surroundings (Milović 2002), Split (Ruščić 2003), Omiš (Tafra et al. 2012) and Zadar (Milović and Mitić 2012). As for the wider Zagreb area, first floristic studies were conducted in the second half of the $19^{\text {th }}$ century by Schlosser and Vukotinović (1857, 1869), Klinggräff (1861-1862) and Neilreich (1869). More numerous studies followed during the $20^{\text {th }}$ century (Gjurašin 1923, Horvatić 1931, Gospodarić 1958, Marković 1970, 1973, 1975, 1978, Randić et al. 1981, Lukač 1988, Ilijanić et al. 1989, Smital et al. 1998) and so far, only a few in the $21^{\text {st }}$ century (Mitić et al. 2007, Nikolić et al. 2007, Hudina et al. 2012, Alegro et al. 2013, Vuković et al. 2013 and Budisavljević et al. 2017). Jelenovac Forest Park was, before our study, a botanically rather unexplored area with only 31 records of vascular plant taxa, 22 of which originate from Herbarium Croaticum collection (ZA) (Rešetnik \& Šegota 2020). Only one herbarium specimen dates back to 1993 , while all other specimens are from 1955 or even earlier. The data on the remaining five records of vascular taxa originate from literature: Hirc (1903, 1912), Bevilacqua (1957), Ilijanić et al. (1994) and Pandža et al. (2001), most of them being secondary references. 


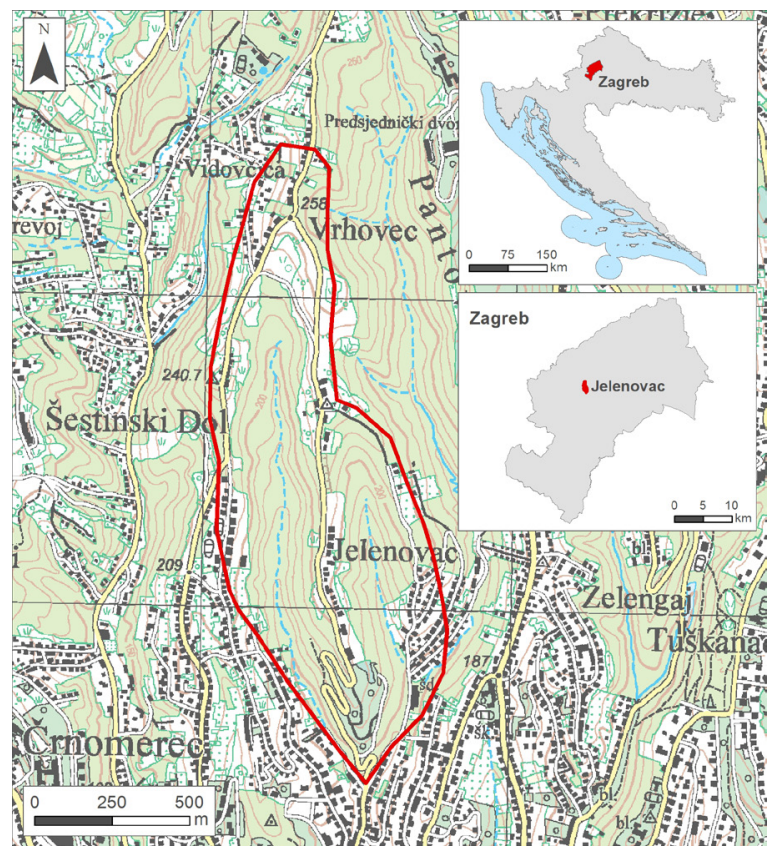

Figure 1. Geographical position of Jelenovac Forest Park.

The aim of this research was to study the vascular plant taxa of the Jelenovac Forest Park; to perform an analysis of the recorded flora according to: taxonomic preferences, chorological types, life-forms, IUCN category, protection status, endemism and invasiveness and to compare the results with those of floristic analyses of other urban and suburban areas.

\section{Materials and methods}

Jelenovac was floristically surveyed during the vegetation season of 2019., from March to June, as a part of a student field project in the practical course "Croatian flora" given at the Faculty of Science, University of Zagreb. The area was searched with the intention of exploring all the habitats. Plants were mostly identified directly in the field, however, some were collected, pressed and dried in order to be identified or additionally confirmed. For this purpose, standard and specialized identification keys and iconographies were used: Horvatić (1954), Jávorka \& Csapody (1991), Tutin et al. (1993), Domac (1994), Alegro et al. (2003), Delforge (2006), Eggenberg \& Mohl (2007), Rothmaler \& Jäger (2007) and Nikolić (2019). All collected plant material was stored in the ZA herbarium collection at the Division of Botany of the Department of Biology, Faculty of Science, University of Zagreb and is publicly available via Flora Croatica Database (Nikolić 2020) and ZA \& ZAHO Virtual Herbarium (Rešetnik \& Šegota 2020).

Rare and protected specimens were not collected but photographed only. Nomenclature was mainly given according to Flora Croatica Database (Nikolić 2020), with the exception of some cultivated and adventitious taxa and varieties (Hosta plantaginea, Pinus peuce, Populus nigra var. italica and Salix $\times$ salamonii) where The Plant List (2020) was used as a nomenclature reference. Taxa were presented in alphabetical order of families, genera and species.

Life-form and chorological type were attributed to each taxon of the checklist. Data from Šegulja (1977), Pignatti (1982) and Ellenberg et al. (1991) were used in the preparation of the life-form spectrum, with the following abbreviations: $\mathrm{Ch}$ - chamaephytes, G - geophytes, H - hemicryptophytes, Hy - hydrophytes, P - phanerophytes and $\mathrm{T}$ - therophytes. Chorological analysis was based on Horvatić (1963) and Horvatić et al. (1968) using the following abbreviations: 1 - Mediterranean floral element, 2 - Illyrian-Balkan floral element, 3 - South-European floral element, 4 - Atlantic floral element, 5 - East-European-Pontic floral element, 6 - Southeast-European floral element, 7 - Central-European floral element, 8 - European floral element, 9 - Eurasian floral element, 10 Circum-holarctic floral element, 11 - widespread plants and 12 - cultivated and adventitious plants.

Spectra of families, life-forms and chorological types were compared with similar urban and suburban areas of Zagreb and surrounding areas such as Stupnik (Mitić et al. 2007), Piškorovo and Konopljenka (Hudina et al. 2012), seminatural marshland Savica (Alegro et al. 2013), Jarun (Vuković et al. 2013) and Dotrščina Forest Park (Budisavljević et al. 2017). 
Data on threat level according to IUCN criteria were taken from the Red Book of the Vascular Flora of Croatia (Nikolić \& Topić 2005) with corresponding abbreviations showing the degree of threat for each taxon as follows: CR - Critically Endangered, EN - Endangered, VU - Vulnerable, NT - Near Threatened, LC - Least Concern and DD - Data Deficient. The legal protection status in Croatia is in accordance with the Ordinance on strictly protected species (Anonymous 2016), while data on endemic, as well as invasive, taxa are obtained from the Flora Croatica Database (Nikolić 2020).

\section{Results and discussion}

Altogether 255 taxa (one identified only to the genus level, 248 species and six subspecies) have been recorded in the flora of Jelenovac Forest Park, belonging to 186 genera and 75 plant families (Appendix 1 ). The most abundant family is Compositae (Asteraceae and Cichoriaceae) (12.55\%), followed by Rosaceae (7.06\%) and Poaceae (6.67\%), while all other families account for less than $4 \%$ each (Tab. 1). The order of families with the highest number of taxa mostly differs from other surveyed localities in Zagreb and its surroundings (Tab. 2) with the exception of Compositae which is the most abundant family in all the surveys. The large share of Rosaceae in the Jelenovac flora is due to the presence of five cultivated trees, one cultivated shrub and one invasive taxon. A similar situation was found in another Zagreb forest park, Dotrščina (Budisavljević et al. 2017). Jelenovac and Dotrščina are dominantly forest areas, whereas the other areas (Stupnik, Piškorovo and Konopljenika, Savica and Jarun) have much more open habitats, the larger share of Poaceae in those floras being thus comprehensible.

Regarding life-form spectrum, almost half of the recorded taxa (43.14\%) are hemicryptophytes, followed by phanerophytes (27.45\%), geophytes (14.12\%) and therophytes (13.33\%) (Fig. 2). In comparison with other floras of Zagreb and its surrounding areas, hemicryptophytes are always dominant, while phanerophytes and therophytes share the second place, depending on the particular area (Tab. 3). Domination of hemicryptophytes and a small percentage of chamaephytes in all compared floras is in accordance with the expected composition of temperate zone life-forms, reflecting the temperate climate of the studied area (Horvat 1942). The share of the next most common life-form, phanerophytes, most closely coincides with the flora of Dotrščina. This correlation is expected given that Jelenovac and Dotrščina are covered primarily by forest vegetation. Another, more important, factor contributing to the considerable share of phanerophytes in the flora of Jelenovac is human intervention as many trees are cultivated and planted for decorative purposes only.

Table 1. Families with the highest number of taxa in the flora of Jelenovac.

\begin{tabular}{|l|ll}
\hline Family & No. of taxa & \% of total flora \\
\hline Compositae & 32 & 12.55 \\
\hline Rosaceae & 18 & 7.06 \\
\hline Poaceae & 17 & 6.67 \\
\hline Lamiaceae & 9 & 3.53 \\
\hline Brassicaceae & 8 & 3.14 \\
\hline Caryophyllaceae & 8 & 3.14 \\
\hline Fabaceae & 8 & 3.14 \\
\hline Polygonaceae & 7 & 2.75 \\
\hline Apiaceae & 6 & 2.35 \\
\hline Boraginaceae & 6 & 2.35 \\
\hline Ranunculaceae & 6 & 2.35 \\
\hline Salicaceae & 6 & 2.35 \\
\hline Scrophulariaceae & 6 & 2.35 \\
\hline other families (62) & 118 & 46.27 \\
\hline
\end{tabular}


Table 2. Comparison of families (in percentages) for Jelenovac and similar urban and suburban areas in Zagreb and its surroundings.

\begin{tabular}{|c|c|c|c|c|c|c|}
\hline Families & Jelenovac & Stupnik & $\begin{array}{l}\text { Piškorovo and } \\
\text { Konopljenika }\end{array}$ & Savica & Jarun & Dotrščina \\
\hline Compositae & 12.6 & 11.5 & 12.2 & 12.5 & 13.7 & 8.0 \\
\hline Rosaceae & 7.1 & 4.7 & 5.4 & 4.8 & 4.0 & 6.4 \\
\hline Poaceae & 6.7 & 8.4 & 11.4 & 11.8 & 11.8 & 5.9 \\
\hline Lamiaceae & 3.5 & 5.8 & 5.7 & 5.9 & 6.8 & 3.5 \\
\hline Fabaceae & 3.1 & 6.0 & 7.4 & 5.2 & 6.8 & 5.9 \\
\hline Brassicaceae & 3.1 & 4.4 & 3.7 & 3.5 & 4.0 & 2.5 \\
\hline Caryophyllaceae & 3.1 & 3.6 & 2.3 & 2.4 & 2.8 & 2.5 \\
\hline
\end{tabular}

Compared to most other floras, that of Jelenovac has a relatively small share of therophytes, although greater than the one recorded in Dotrščina Forest Park. Given the forest cover of the studied area, a small share of therophytes was to be expected, as they mostly fail to grow in the shade of trees. However, due to the research area location in the urban area surrounded by private gardens and open areas, it is not surprising that the share of therophytes is greater than in the Dotrščina Forest Park. Unlike therophytes, geophytes tend to grow in the shade of trees and therefore occur to a lesser extent in the floras of open areas such as Stupnik, Piškorovo and Konopljenika and Savica.

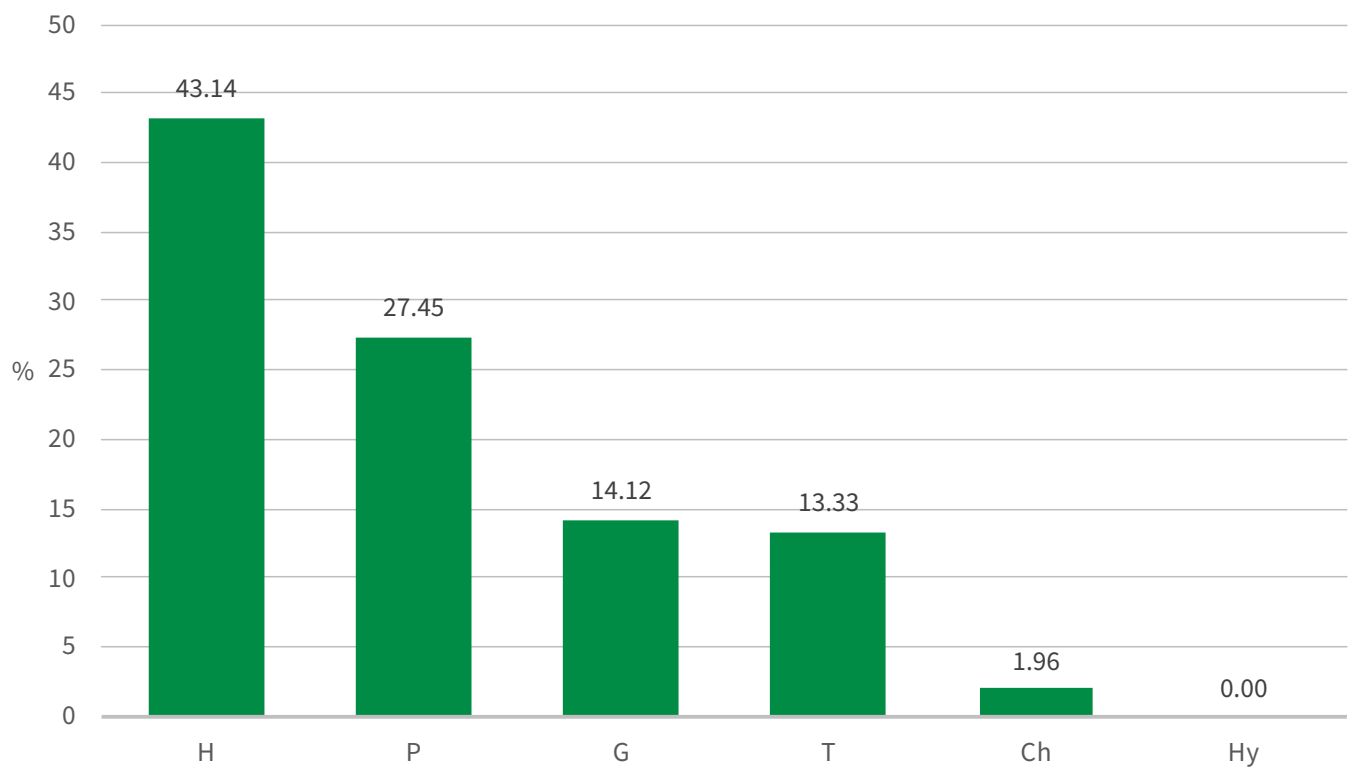

Figure 2. Life-form spectrum for the flora of Jelenovac $(\mathrm{H}$ - hemicryptophytes, $\mathrm{P}$ - phanerophytes, G - geophytes, T - therophytes, Ch - chamaephytes, Hy - hydrophytes). 
Table 3. Comparison of life-form ratios (in percentages) for Jelenovac and similar urban and suburban areas in Zagreb and its surroundings.

$\begin{array}{llllllll}\text { Life-forms } & \text { Jelenovac } & \text { Stupnik } & \begin{array}{l}\text { Piškorovo and } \\ \text { Konopljenika }\end{array} & \text { Savica } & \text { Jarun } & \text { Dotrščina } \\ \text { Hemicryptophytes } & 43.1 & 49.6 & 48.1 & 47.9 & 42.4 & 47.4 \\ \text { Phanerophytes } & 27.5 & 10.9 & 14.5 & 14.2 & 13.0 & 20.9 \\ \text { Geophytes } & 14.1 & 10.0 & 10.8 & 10.1 & 16.1 & 17.5 \\ \text { Therophytes } & 13.3 & 24.0 & 22.2 & 19.1 & 24.8 & 9.5 \\ \text { Chamaephytes } & 2.0 & 3.1 & 3.1 & 1.4 & 1.9 & 4.7 \\ \text { Hydrophytes } & 0.0 & 2.4 & 1.1 & 5.9 & 1.9 & 0.0\end{array}$

The recorded taxa belong to a total of ten floral elements (Fig. 3), with the domination of Eurasian floral element (27.45\%), followed by widespread plants (22.35\%), cultivated and adventitious plants (18.04\%) and South-European floral element (8.34\%), while other life forms account for less than $4 \%$ each. Even though the Eurasian floral element always dominates in the floras compared and the shares of some floral elements do correlate, orders of dominance generally do not coincide with the order of dominance of the flora of Jelenovac (Tab. 4). High share of widespread plants and comparatively lower shares of other chorological types in our survey as well as in the floras of Stupnik and Piškorovo and Konopljenika can be largely explained by the use of different approaches in detection of chorological types. In determining the chorological types of Stupnik, Piškorovo and Konopljenika and Jelenovac, Horvatić (1963) and Horvatić et al. (1968) were primarily used, while in Savica, Jarun and Dotrščina, Landolt et al. (2010) was used, either completely or for revision purposes. In spectra made according to Landolt et. al. (2010) a significantly lower share of widespread plants was recorded because since the work of Horvatic et al. (1968) the distribution of many species has become better understood. The higher percentage of cultivated plants than in other related floras is explained by the partially ornamental purpose of the studied area.

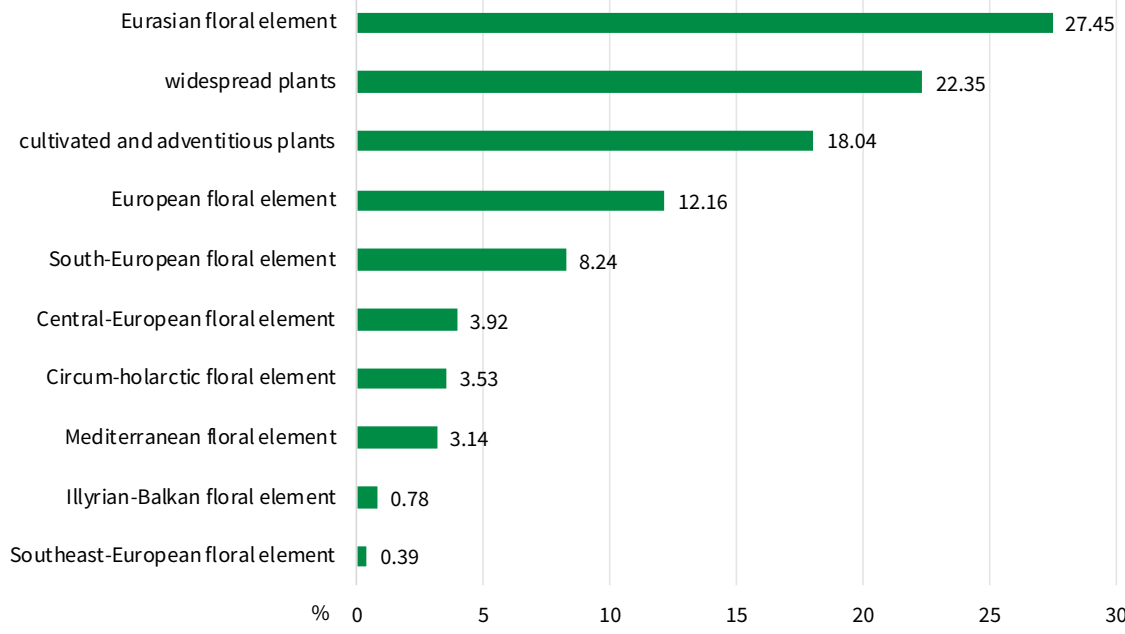

Figure 3. Chorological spectrum for the flora of Jelenovac. 
Table. 4. Comparison of chorotype ratios (in percentages) for Jelenovac and similar urban and suburban areas in Zagreb and its surroundings.

\begin{tabular}{|c|c|c|c|c|c|c|}
\hline Chorological type & Jelenovac & Stupnik & $\begin{array}{l}\text { Piškorovo and } \\
\text { Konopljenika }\end{array}$ & Savica & Jarun & Dotrščina \\
\hline Eurasian floral element & 27.5 & 32.5 & 30.1 & 48.3 & 44.1 & 44.1 \\
\hline widespread plants & 22.4 & 27.7 & 27.0 & 3.1 & 8.4 & 2.5 \\
\hline cultivated and adventitious plants & 18.0 & 3.7 & 10.2 & 13.2 & 9.9 & 5.9 \\
\hline European floral element & 12.2 & 11.5 & 11.1 & 3.8 & 7.8 & 4.0 \\
\hline South-European floral element & 8.2 & 9.0 & 9.1 & 3.1 & 7.8 & 5.4 \\
\hline Central-European floral element & 3.9 & 4.2 & 3.1 & 6.3 & 5.9 & 17.8 \\
\hline Circum-holarctic floral element & 3.5 & 7.3 & 6.3 & 8.7 & 5.3 & 4.5 \\
\hline Mediterranean floral element & 3.1 & 2.0 & 1.4 & 9.7 & 9.6 & 10.4 \\
\hline Illyrian-Balkan floral element & 0.8 & 0.2 & 0.0 & 0.7 & 0.3 & 2.5 \\
\hline Southeast-European floral element & 0.4 & 0.4 & 0.6 & 1.0 & 0.0 & 1.0 \\
\hline East-European-Pontic floral element & 0.0 & 0.9 & 1.1 & 2.1 & 0.9 & 1.5 \\
\hline Atlantic floral element & 0.0 & 0.4 & 0.0 & 0.0 & 0.0 & 0.5 \\
\hline
\end{tabular}

Seven recorded taxa are classified into one of the IUCN categories, but only one (Taxus baccata) belongs to one of the threatened categories and is classified as Vulnerable (VU), while other taxa belong either to Near Threatened (NT) (Cephalanthera damasonium, Cyclamen purpurascens and Daphne laureola) or Least Concern (LC) (Hordeum murinum ssp. murinum, Poa annua and Ruscus aculeatus) category. In total, three taxa (Taxus baccata, Cephalanthera damasonium and Neottia nidus-avis) are classified as strictly protected in Croatia and none as endemic.

In the study area, 12 invasive taxa (Acer negundo, Ailanthus altissima, Artemisia verlotiorum, Chamomilla suaveolens, Datura stramonium, Duchesnea indica, Erigeron annuus, Reynoutria $\mathrm{x}$ bohemica, Robinia pseudoacacia, Solidago canadensis, Solidago gigantea and Veronica persica) were recorded, accounting for $4.71 \%$ of the total flora of Jelenovac. Among them, as expected, as many as five taxa belong to the family Compositae, the family with the biggest number of invasive taxa in Croatia and Europe. None of the existing invasive taxa covered a considerable area and were, as expected, mainly recorded along the edge of the forest in disturbed areas along pathways, streets and near households. Proximity to the city leads to nitrogen accumulation in the living systems while many surrounding private houses with their gardens allow alien and potentially invasive plants to thrive, consequently putting open areas and forest edges, under a certain anthropogenic pressure. Therefore, given the location of the studied area, the number of 12 recorded invasive taxa was to be expected. Although there are not large areas 
covered by invasive plants and they have not yet progressed into the forest, monitoring should be established and habitat degradation, such as logging and construction, should be prevented in order to conserve the forest in its original form and disable the future spread of existing invaders.

Jelenovac Forest Park, with its 255 recorded taxa, is floristically relatively rich forest area of Zagreb when compared with similar, but larger Dotrščina Forest Park, with 202 taxa recorded. The floral composition reflects the character of the studied area as an anthropogenically influenced, managed and maintained forest with a partly ornamental purpose, daily visited and used by people for recreational activity and socializing. Therefore, given the anthropogenic pressure present in the area, the larger share of adventitious taxa compared to similar urban and suburban areas was as expected. Nevertheless, its original floristic composition is still well preserved and generally resembles other, similar, suburban areas in Zagreb and its surroundings, making it a valuable source of plant diversity in the very centre of the city of Zagreb. Therefore, the results of this research represent a relevant addition to the knowledge of the urban flora of Zagreb and Croatian flora in general and can further serve as the basis for monitoring changes in the following period.

\section{Acknowledgments}

We express our appreciation to our colleague Anja Rimac for her help in designing the geographical position map.

\section{Literature}

Alegro, A. (2003): Bromus. In: Nikolić, T. (ed.): Ključevi za određivanje svojti kritičnih skupina. Botanički zavod PMF-a. Interna verzija br. 01.

Alegro, A., Bogdanović, S., Rešetnik, I., Boršić, I., Cigić, P., Nikolić, T. (2013): Flora of the seminatural marshland Savica, part of the (sub) urban flora of the city of Zagreb (Croatia). Natura Croatica 22(1): 111-134.
Anonymous (2016): Pravilnik o izmjenama i dopunama Pravilnika o strogo zaštićenim vrstama (Narodne novine 73/2016).

Anonymous (2020a): Croatian Agency for Environment and Nature: Bioportal - TK25. http:// bioportal.hr/ (accessed April 24, 2020).

Anonymous (2020b): Croatian Agency for Environment and Nature: Bioportal - Kopnena staništa - poligon. http://bioportal.hr/ (accessed April 24, 2020).

Bevilacqua, B. (1957): Revizija studentskog herbara. Master's Thesis, Faculty of Science, University of Zagreb, Zagreb.

Budisavljević, A., Terlević, A., Mihelić, P., Špadina, B., Papković, D., Nikolić, T., Šegota, V. (2017): Vascular flora of the Dotrščina forest (Zagreb, Hrvatska). Glasnik Hrvatskog botaničkog društva 5(1): 4-19.

Delforge, P. (2006): Orchids of Europe, North Africa and Middle East. 3rd ed. A\&C Black Publisher Ltd., London.

Domac, R. (1994): Flora Hrvatske. Priručnik za određivanje bilja. Školska knjiga, Zagreb.

Ellenberg, H., Weber, H. E., Düll, R., Wirth, V.,Werner, W., Paulißen, D. (1991): Zeigerwerte von Pflanzen in Mitteleuropa. Scripta Geobotanica 18: 1-248.

Eggenberg, S., Möhl, A. (2007): Flora Vegetativa. Ein Bestimmungsbuch für Pflanzen der Schweiz im blütenlosen Zustand. Haupt Ver., Bern-Stuttgart-Wien.

Gjurašin, S. (1923): Dodatak flori Zagrebačke okolice. Glasnik Hrvatskoga prirodoslovnoga društva 35(1/2): 138-141.

Gospodarić, Lj. (1958): Novi prilog flori okolice Zagreba. Acta Botanica Croatica 17: 151-157.

Hirc D. (1903): Revizija hrvatske flore (Revisio florae Croaticae). Rad Jugoslavenske akademije znanosti i umjetnosti 155: 49-158.

Hirc, D. (1912): Revizija hrvatske flore (Revisio florae Croaticae). Rad Jugoslavenske akademije znanosti i umjetnosti 190: 170-275.

Horvat, I. (1949): Nauka o biljnim zajednicama. Nakladni zavod Hrvatske, Zagreb. 
Horvatić, S. (1931): Bilješke o nekim manje poznatim biljkama iz hrvatske flore. Acta Botanica Instituti Botanici Universitatis Zagrebensis 6: 56-65.

Horvatić, S. (1954): Ilustrirani bilinar. Priručnik za određivanje porodica i rodova višega bilja. Školska knjiga, Zagreb.

Horvatić, S. (1963): Vegetacijska karta otoka Paga s općim pregledom vegetacijskih jedinica Hrvatskog primorja. Zagreb. Prirodoslovna Istraživanja Jugoslavenske Akademije 33. Acta Biologica 4.

Horvatić, S., Ilijanić, Lj., Marković-Gospodarić, Lj. (1968): Biljni pokrov okolice Senja. Senjski zbornik 3: 298-322.

Hudina, T., Salkić, B., Rimac, A., Bogdanović, S., Nikolić, T. (2012): Contribution to the urban flora of Zagreb (Croatia). Natura Croatica 21(2): 357-372.

Ilijanić, Lj., Hršak, V., Juričić, Ž., Hršak, J. (1989): Influence of air pollution on the bark $\mathrm{pH}$-values in the regions of Zagreb and Sisak. Acta Botanica Croatica 48: 63-73.

Ilijanić, Lj., Marković, Lj., Stančić, Z. (1994): Impatiens balfourii Hooker fil. in Kroatien. Acta Botanica Croatica 53: 115-119.

Jávorka, S., Csapody, V. (1991): Iconographiae florae partis Austro-orientalis Europae centralis. Akadémiai Kiadó, Budapest.

Klinggräff, H. (1861-1862): Die in der Umgegend von Agram in Croatien vorkommenden Pflanzen. Linnaea 1: 6-62.

Lukač, G. (1988): Neke značajke strukture sastojina Solidago gigantea i Helianthus tuberosus i njihove ornitocenoze u sjeverozapadnoj Hrvatskoj. Acta Botanica Croatica 47: 63-75.

Marković, Lj. (1970): Prilozi neofitskoj flori savskih obala u Hrvatskoj. Acta Botanica Croatica 29: 203-211.

Marković, Lj. (1973): Sporobolus neglectus Nash, nova adventivna vrsta Jugoslavije. Acta Botanica Croatica 32: 237-242.

Marković, Lj. (1975): O vegetaciji sveze Bidention tripartiti u Hrvatskoj. Acta Botanica Croatica 34: 103-120.
Marković, Lj. (1978): Travnjačka vegetacija sveze Agropyro-Rumicion u obalnom pojasu Save $\mathrm{u}$ Hrvatskoj. Acta Botanica Croatica 37: 107-130.

Milović, M. (2002): The flora of Šibenik and its surroundings. Natura Croatica 11(2): 171-223.

Milović, M., Mitić, B. (2012): The urban flora of the city of Zadar (Dalmatia, Croatia). Natura Croatica 21(1): 65-100.

Mitić, B., Kajfeš, A., Cigić, P., Rešetnik, I. (2007): The flora of Stupnik and its surroundings (Northwest Croatia). Natura Croatica 16(2): 147-169.

Neilreich, A. (1869): Nachträge zu den Vegetationverhältnissen von Croatien. Verh. K.- K. Zool.-Bot. Ges. Wien 19: 756-830.

Nikolić, T. (2019): Flora croatica 4: Vaskularna flora Republike Hrvatske. Alfa d. d. Zagreb.

Nikolić, T. (ed.) (2020): Flora Croatica Database. Department of Botany, Faculty of Science, University of Zagreb. http://hirc.botanic.hr/fcd (accessed April 25, 2020).

Nikolić, T., Topić, J. (2005): Crvena knjiga vaskularne flore Hrvatske. Ministarstvo kulture, Državni zavod za zaštitu prirode, Zagreb.

Nikolić, T., Rešetnik, I., Alegro, A., Cigić, P., Boršić, I., Bogdanović, S. (2007): Inventarizacija flore. Prilog za izradu prostornog plana područja posebnih obilježja - priobalje Save - krajobraz uz Savu - Savski park, I etapa - Savica. Prirodoslovno-matematički fakultet Sveučilišta u Zagrebu, Biološki odsjek, Zagreb.

Pandža, M., Franjić, J., Trinajstić, I., Škvorc, Ž., Stančić, Z. (2001): The most recent state of affairs in the distribution of some neophytes in Croatia. Natura Croatica 10(4): 259-275.

Pignatti, S. (1982): Flora d'Italia. I-III. Edagricole, Bologna.

Pyšek, P., Chytrý, M., Jarošík, V. (2010): Habitats and land use as determinants of plant invasions in the temperate zone of Europe. In: Perrings, C., Moony, H., Williamson, M. (eds.): Bioinvasions and globalisation. Ecology, economics, management and policy. Oxford University Press, Oxford, 66-79. 
Randić, M., Buble, J., Buljan, D., Dundara, D., Hladik, M., Milović, M., Otahal, G., Pavičić, J., Pavletić, I., Petrović, S., Stojanović, S., Šmaguc, Ž., Štrkalj, O., Vovk, N., Žunec, R. (1981): Prilog poznavanju flore okolice Zagreba. U: Springer, O., Gomerčić, H. (ur.): Zbornik sažetaka priopćenja Prvog kongresa biologa Hrvatske. Hrvatsko biološko društvo, Zagreb, 99-100.

Rešetnik, I., Šegota, V. (eds.) (2020). Virtual herbarium ZA and ZAHO. University of Zagreb, Faculty of Science. http://herbariumcroaticum.biol.pmf.hr (accessed April 24, 2020).

Rothmaler, W., Jäger, E. J. (2007): Exkursionsflora von Deutschland. Band 3 - Gefäßpflanzen: Atlasband. Elsevier Spektrum Akademischer Verlag, Heidelberg-Berlin.

Ruščić, M. (2003): Urbana flora grada Splita. MSc Thesis. Faculty of Science. University of Zagreb, Zagreb.

Schlosser, J. C. K., Vukotinović, Lj. (1857): Syllabus florae croaticae. Typis Dr. Ludovici Gaj, Zagrabia.

Schlosser, J. C. K., Vukotinović, Lj. (1869): Flora Croatica. Sumptibus et auspiciis academiae scientiarum et articum slavorum meridionalium, Zagreb.
Smital, A., Marković, Lj., Ruščić, M. (1998): O širenju vrste Artemisia verlotiorum Lamotte $\mathrm{u}$ Hrvatskoj. Acta Botanica Croatica 55/56: 53-63. Šegota, T., Filipčić, A. (2003): Köppenova podjela klima i hrvatsko nazivlje. Geoadria 8/1: 17-37.

Šegulja, N. (1977): Analiza flore Vukomeričkih Gorica. Biosistematika 3(1): 45-59.

Tafra, D., Pandža, M., Milović, M. (2012): Vascular flora of the town of Omiš. Natura Croatica 21(2): 301-334.

The Plant List (2020): Version 1.1. Published on the Internet. http://www.theplantlist.org/ (accessed April 24, 2020).

Tutin, T. G., Burges, N. A., Chater, A.O., Edmondson, J. R., Heywood, W. H., Moore, D. M., Valentine, D. H., Walters, S. M. \& Webb, D. A. (1993): Flora Europaea 1 (2nd ed.), Cambridge University press, Cambridge.

Vuković, N., Boršić, I., Župan, D., Alegro, A., Nikolić, T. (2013): Vascular flora of Jarun (Zagreb, Croatia). Natura Croatica 22(2): 275-294. 
Appendix 1. The list of vascular plant taxa recorded in Jelenovac Forest Park.

\begin{tabular}{|c|c|c|c|c|c|c|}
\hline Family & Taxon & $\begin{array}{l}\text { ¿ } \\
\sum_{2}^{2} \\
\frac{0}{0} \\
\frac{c}{0}\end{array}$ & & 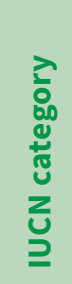 & 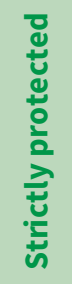 & 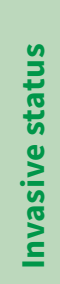 \\
\hline \multicolumn{7}{|c|}{ MONILOPHYTA (PTERIDOPHYTA) } \\
\hline Dryopteridaceae & Dryopteris filix-mas (L.) Schott & 11 & G & & & \\
\hline Equisetaceae & Equisetum arvense L. & 10 & G & & & \\
\hline Hypolepidaceae & Pteridium aquilinum (L.) Kuhn & 11 & G & & & \\
\hline \multicolumn{7}{|c|}{ SPERMATOPHYTA - GYMNOSPERMAE } \\
\hline Cupressaceae & Thuja orientalis L. & 12 & $\mathrm{P}$ & & & \\
\hline \multirow[t]{3}{*}{ Ginkgoaceae } & Ginkgo biloba L. & 12 & $\mathrm{P}$ & & & \\
\hline & Abies alba Mill. & 3 & $P$ & & & \\
\hline & Picea abies (L.) H. Karst. & 12 & $\mathrm{P}$ & & & \\
\hline \multirow[t]{3}{*}{ Pinaceae } & Pinus peuce Griseb. & 12 & $\mathrm{P}$ & & & \\
\hline & Pinus nigra J. F. Arnold & 3 & $\mathrm{P}$ & & & \\
\hline & Tsuga canadensis (L.) Carriere & 12 & $\mathrm{P}$ & & & \\
\hline Taxaceae & Taxus baccata $\mathrm{L}$. & 9 & $\mathrm{P}$ & VU & + & \\
\hline \multicolumn{7}{|c|}{ SPERMATOPHYTA - ANGIOSPERMAE } \\
\hline \multicolumn{7}{|l|}{ MAGNOLIANAE } \\
\hline Aristolochiaceae & Asarum europaeum L. & 9 & $\mathrm{H}$ & & & \\
\hline \multicolumn{7}{|l|}{ LILIANAE } \\
\hline \multirow[t]{2}{*}{ Agavaceae } & Yucca filamentosa L. & 12 & $\mathrm{P}$ & & & \\
\hline & Allium schoenoprasum L. & 10 & G & & & \\
\hline \multirow[t]{2}{*}{ Amaryllidaceae } & Allium ursinum $\mathrm{L}$. & 9 & G & & & \\
\hline & Narcissus pseudonarcissus L. & 12 & G & & & \\
\hline \multirow[t]{3}{*}{ Araceae } & Arum maculatum L. & 8 & G & & & \\
\hline & Hosta plantaginea (Lam.) Asch. & 12 & G & & & \\
\hline & Muscari neglectum Guss. ex Ten. & 1 & G & & & \\
\hline \multirow[t]{5}{*}{ Asparagaceae } & Polygonatum multiflorum (L.) All. & 10 & G & & & \\
\hline & Polygonatum odoratum (Mill.) Druce & 10 & G & & & \\
\hline & Ruscus aculeatus L. & 1 & G & LC & & \\
\hline & Carex divulsa Stokes & 11 & $\mathrm{H}$ & & & \\
\hline & Carex hirta L. & 9 & G & & & \\
\hline \multirow{2}{*}{ Cyperaceae } & Carex sylvatica Huds. & 8 & $\mathrm{H}$ & & & \\
\hline & Carex vulpina L. & 8 & $\mathrm{H}$ & & & \\
\hline \multirow{2}{*}{$\begin{array}{l}\text { Dioscoreaceae } \\
\text { Iridaceae }\end{array}$} & Tamus communis L. & 3 & G & & & \\
\hline & Crocus vernus (L.) Hill & 6 & G & & & \\
\hline
\end{tabular}




\begin{tabular}{|c|c|c|c|c|c|c|}
\hline \multirow[t]{2}{*}{ Family } & Taxon & $\begin{array}{l}\frac{0}{2} \\
\frac{2}{0} \\
\frac{0}{0} \\
\frac{0}{u}\end{array}$ & & 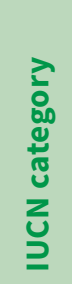 & 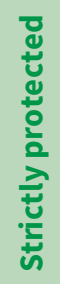 & 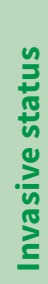 \\
\hline & Juncus effusus L. & 11 & $\mathrm{H}$ & & & \\
\hline \multirow{3}{*}{ Juncaceae } & Luzula campestris (L.) DC. & 11 & $\mathrm{H}$ & & & \\
\hline & Luzula forsteri (Sm.) DC. & 3 & $\mathrm{H}$ & & & \\
\hline & Luzula pilosa (L.) Willd. & 10 & $\mathrm{H}$ & & & \\
\hline \multirow{2}{*}{ Liliaceae } & Erythronium dens-canis L. & 3 & G & & & \\
\hline & Gagea lutea (L.) Ker Gawl. & 9 & G & & & \\
\hline \multirow{2}{*}{ Orchidaceae } & Cephalanthera damasonium (Mill.) Druce & 3 & G & NT & + & \\
\hline & Neottia nidus-avis (L.) Rich. & 9 & G & & + & \\
\hline \multirow{17}{*}{ Poaceae } & Alopecurus pratensis L. & 9 & $\mathrm{H}$ & & & \\
\hline & Anthoxanthum odoratum L. & 9 & $\mathrm{H}$ & & & \\
\hline & Arrhenatherum elatius (L.) J. Presl et C. Presl & 8 & $\mathrm{H}$ & & & \\
\hline & Brachypodium sylvaticum (Huds.) P. Beauv. & 9 & $\mathrm{H}$ & & & \\
\hline & Briza media L. & 9 & $\mathrm{~T}$ & & & \\
\hline & Bromus sterilis L. & 11 & $\mathrm{~T}$ & & & \\
\hline & Dactylis glomerata $\mathrm{L}$. & 9 & $\mathrm{H}$ & & & \\
\hline & Elymus repens (L.) Gould & 11 & G & & & \\
\hline & Festuca drymeja Mert. Koch & 3 & $\mathrm{H}$ & & & \\
\hline & Holcus lanatus L. & 9 & $\mathrm{H}$ & & & \\
\hline & Hordeum murinum L. ssp. murinum & 11 & $\mathrm{~T}$ & LC & & \\
\hline & Lolium perenne L. & 8 & $\mathrm{H}$ & & & \\
\hline & Melica nutans L. & 8 & $\mathrm{H}$ & & & \\
\hline & Poa annua L. & 11 & $\mathrm{~T}$ & LC & & \\
\hline & Poa pratensis L. & 11 & $\mathrm{H}$ & & & \\
\hline & Poa trivialis $\mathrm{L}$. & 9 & $\mathrm{H}$ & & & \\
\hline & Setaria viridis (L.) P. Beauv. & 9 & $\mathrm{~T}$ & & & \\
\hline \multicolumn{7}{|c|}{ EUDICOTYLEDONAE } \\
\hline \multirow{4}{*}{ Aceraceae } & Acer campestre L. & 8 & $\mathrm{P}$ & & & \\
\hline & Acer negundo L. & 12 & $P$ & & & + \\
\hline & Acer platanoides L. & 8 & $P$ & & & \\
\hline & Acer pseudoplatanus L. & 8 & $\mathrm{P}$ & & & \\
\hline \multirow{3}{*}{$\begin{array}{l}\text { Adoxaceae } \\
\text { Anacardiaceae }\end{array}$} & Adoxa moschatellina L. & 10 & G & & & \\
\hline & Rhus typhina L. & 12 & $P$ & & & \\
\hline & Aegopodium podagraria L. & 9 & $\mathrm{H}$ & & & \\
\hline \multirow{5}{*}{ Apiaceae } & Anthriscus cerefolium (L.) Hoffm. & 8 & $\mathrm{H}$ & & & \\
\hline & Anthriscus sylvestris (L.) Hoffm. & 9 & $\mathrm{H}$ & & & \\
\hline & Daucus carota $\mathrm{L}$. & 9 & $\mathrm{H}$ & & & \\
\hline & Heracleum sphondylium L. & 9 & $\mathrm{H}$ & & & \\
\hline & Sanicula europaea L. & 11 & $\mathrm{H}$ & & & \\
\hline
\end{tabular}




\begin{tabular}{|c|c|c|c|c|}
\hline Family & Taxon & $\begin{array}{l}\text { ㅁ } \\
\text { 은 } \\
\text { 은 }\end{array}$ & 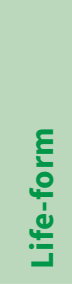 & 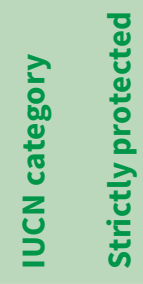 \\
\hline \multirow{2}{*}{ Apocynaceae } & Vinca major L. & 12 & $\mathrm{Ch}$ & \\
\hline & Vinca minor L. & 8 & $\mathrm{Ch}$ & \\
\hline \multirow[t]{2}{*}{ Araliaceae } & Hedera helix L. & 8 & $\mathrm{P}$ & \\
\hline & Berberis vulgaris L. & 9 & $\mathrm{P}$ & \\
\hline \multirow[t]{2}{*}{ Berberidaceae } & Epimedium alpinum L. & 9 & $\mathrm{H}$ & \\
\hline & Mahonia aquifolium (Pursh.) Nutt. & 12 & $\mathrm{P}$ & \\
\hline \multirow[t]{2}{*}{ Betulaceae } & Betula pendula Roth & 9 & $\mathrm{P}$ & \\
\hline & Campsis radicans (L.) Seen. & 12 & $\mathrm{P}$ & \\
\hline \multirow{3}{*}{ Bignoniaceae } & Catalpa bignonioides Walter & 12 & $\mathrm{P}$ & \\
\hline & Borago officinalis L. & 1 & $\mathrm{~T}$ & \\
\hline & Myosotis ramosissima Rochel & 9 & $\mathrm{~T}$ & \\
\hline \multirow{7}{*}{ Boraginaceae } & Myosotis sparsiflora Pohl & 9 & $\mathrm{~T}$ & \\
\hline & Omphalodes verna Moench & 7 & $\mathrm{H}$ & \\
\hline & Pulmonaria officinalis L. & 8 & $\mathrm{H}$ & \\
\hline & Symphytum tuberosum L. & 7 & G & \\
\hline & Alliaria petiolata (M. Bieb.) Cavara et Grande & 9 & $\mathrm{H}$ & \\
\hline & Armoracia rusticana P. Gaertn. , B. Mey. et Scherb. & 11 & G & \\
\hline & Capsella bursa-pastoris (L.) Medik. & 11 & $\mathrm{H}$ & \\
\hline \multirow{5}{*}{ Brassicaceae } & Cardamine bulbifera (L.) Crantz & 8 & G & \\
\hline & Cardamine hirsuta L. & 11 & $\mathrm{~T}$ & \\
\hline & Cardaria draba (L.) Desv. & 11 & $\mathrm{H}$ & \\
\hline & Rorippa sylvestris (L.) Besser & 9 & $\mathrm{H}$ & \\
\hline & Sisymbrium officinale (L.) Scop. & 11 & $\mathrm{~T}$ & \\
\hline \multirow[t]{2}{*}{ Cannabaceae } & Humulus lupulus L. & 9 & $\mathrm{P}$ & \\
\hline & Lonicera caprifolium L. & 3 & $\mathrm{P}$ & \\
\hline \multirow{6}{*}{ Caprifoliaceae } & Lonicera pileata Oliv. & 12 & $\mathrm{P}$ & \\
\hline & Sambucus nigra L. & 8 & $P$ & \\
\hline & Symphoricarpos orbiculatus Moench & 12 & $\mathrm{P}$ & \\
\hline & Cerastium glomeratum Thuill. & 11 & $\mathrm{~T}$ & \\
\hline & Cerastium pumilum Curtis ssp. glutinosum (Fr.) Jalas & 11 & $\mathrm{~T}$ & \\
\hline & Lychnis flos-cuculi L. & 9 & $\mathrm{H}$ & \\
\hline \multirow[t]{5}{*}{ Caryophyllaceae } & $\begin{array}{l}\text { Silene italica (L.) Pers. ssp. nemoralis (Waldst. et } \\
\text { Kit.) Nyman }\end{array}$ & 3 & $\mathrm{H}$ & \\
\hline & Stellaria graminea L. & 9 & $\mathrm{H}$ & \\
\hline & Stellaria holostea L. & 9 & $\mathrm{Ch}$ & \\
\hline & Stellaria media (L.) Vill. & 11 & $\mathrm{~T}$ & \\
\hline & Stellaria nemorum L. & 8 & $\mathrm{H}$ & \\
\hline
\end{tabular}




\begin{tabular}{|c|c|c|c|c|c|c|}
\hline Family & Taxon & 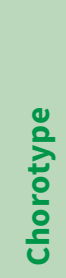 & 혼 & 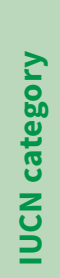 & 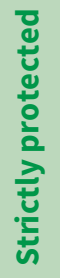 & 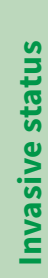 \\
\hline \multirow{18}{*}{$\begin{array}{l}\text { Celastraceae } \\
\text { Clusiaceae }\end{array}$} & Euonymus europaeus L. & 9 & $\mathrm{P}$ & & & \\
\hline & Hypericum perforatum L. & 11 & $\mathrm{H}$ & & & \\
\hline & Achillea millefolium $\mathrm{L}$. & 11 & $\mathrm{H}$ & & & \\
\hline & Aposeris foetida (L.) Less. & 3 & $\mathrm{H}$ & & & \\
\hline & Arctium lappa L. & 9 & $\mathrm{H}$ & & & \\
\hline & Arctium nemorosum Lej. & 9 & $\mathrm{H}$ & & & \\
\hline & Artemisia verlotiorum Lamotte & 12 & $\mathrm{H}$ & & & + \\
\hline & Artemisia vulgaris $\mathrm{L}$. & 11 & $\mathrm{H}$ & & & \\
\hline & Bellis perennis L. & 7 & $\mathrm{H}$ & & & \\
\hline & Calendula officinalis L. & 12 & $\mathrm{~T}$ & & & \\
\hline & Centaurea jacea L. & 9 & $\mathrm{H}$ & & & \\
\hline & Chamomilla suaveolens (Pursh) Rydb. & 11 & $\mathrm{~T}$ & & & + \\
\hline & Cichorium intybus L. & 11 & $\mathrm{H}$ & & & \\
\hline & Cirsium arvense (L.) Scop. & 9 & $\mathrm{~T}$ & & & \\
\hline & Cirsium vulgare (Savi) Ten. & 9 & $\mathrm{H}$ & & & \\
\hline & Crepis vesicaria L. ssp. taraxacifolia (Thuill.) Thell. & 1 & $\mathrm{~T}$ & & & \\
\hline & Doronicum austriacum Jacq. & 3 & $\mathrm{H}$ & & & \\
\hline & Erigeron annuus (L.) Pers. & 12 & $\mathrm{H}$ & & & + \\
\hline \multirow[t]{16}{*}{ Compositae } & Eupatorium cannabinum L. & 9 & $\mathrm{H}$ & & & \\
\hline & Hieracium murorum L. & 9 & $\mathrm{H}$ & & & \\
\hline & Lactuca serriola $\mathrm{L}$. & 11 & $\mathrm{~T}$ & & & \\
\hline & Lapsana communis L. & 9 & $\mathrm{~T}$ & & & \\
\hline & Leucanthemum vulgare Lam. & 9 & $\mathrm{H}$ & & & \\
\hline & Prenanthes purpurea L. & 7 & $\mathrm{H}$ & & & \\
\hline & Senecio vulgaris $\mathrm{L}$. & 11 & $\mathrm{~T}$ & & & \\
\hline & Solidago canadensis L. & 12 & $\mathrm{H}$ & & & + \\
\hline & Solidago gigantea Aiton & 12 & $\mathrm{H}$ & & & + \\
\hline & Sonchus asper (L.) Hill & 9 & $\mathrm{~T}$ & & & \\
\hline & Sonchus oleraceus L. & 11 & $\mathrm{~T}$ & & & \\
\hline & Tanacetum corymbosum (L.) Sch. Bip. & 7 & $\mathrm{H}$ & & & \\
\hline & Tanacetum vulgare L. & 9 & $\mathrm{H}$ & & & \\
\hline & Taraxacum officinale Weber & 11 & $\mathrm{H}$ & & & \\
\hline & Tragopogon pratensis L. ssp. orientalis (L.) Čelak. & 9 & $\mathrm{H}$ & & & \\
\hline & Tussilago farfara L. & 9 & G & & & \\
\hline
\end{tabular}




\begin{tabular}{|c|c|c|c|c|c|}
\hline Family & Taxon & 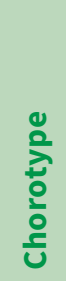 & 힐 & 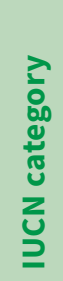 & 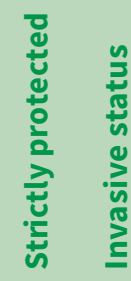 \\
\hline \multirow{2}{*}{ Cornaceae } & Cornus mas L. & 3 & $\mathrm{P}$ & & \\
\hline & Cornus sanguinea $\mathrm{L}$. & 8 & $P$ & & \\
\hline \multirow{2}{*}{ Corylaceae } & Carpinus betulus L. & 7 & $\mathrm{P}$ & & \\
\hline & Corylus avellana $\mathrm{L}$. & 8 & $\mathrm{P}$ & & \\
\hline \multirow{3}{*}{ Crassulaceae } & Sedum ochroleucum Chaix & 3 & $\mathrm{Ch}$ & & \\
\hline & Sedum sarmentosum Bunge & 12 & $\mathrm{Ch}$ & & \\
\hline & Dipsacus fullonum L. & 11 & $\mathrm{H}$ & & \\
\hline \multirow[t]{3}{*}{ Dipsacaceae } & Knautia arvensis (L.) Coult. & 9 & $\mathrm{H}$ & & \\
\hline & Knautia drymeia Heuff. & 3 & $\mathrm{H}$ & & \\
\hline & Euphorbia cyparissias L. & 9 & $\mathrm{H}$ & & \\
\hline \multirow{3}{*}{ Euphorbiaceae } & Euphorbia dulcis L. & 7 & G & & \\
\hline & Euphorbia peplus L. & 11 & $\mathrm{~T}$ & & \\
\hline & Euphorbia virgata Waldst. et Kit. & 9 & $\mathrm{H}$ & & \\
\hline \multirow{8}{*}{ Fabaceae } & Lathyrus niger (L.) Bernhardt & 8 & G & & \\
\hline & Lathyrus vernus (L.) Bernhardt & 8 & G & & \\
\hline & Lotus corniculatus L. & 11 & $\mathrm{H}$ & & \\
\hline & Robinia pseudoacacia L. & 12 & $P$ & & + \\
\hline & Trifolium pratense L. & 9 & $\mathrm{H}$ & & \\
\hline & Trifolium repens L. & 11 & $\mathrm{H}$ & & \\
\hline & Vicia cracca L. & 9 & $\mathrm{H}$ & & \\
\hline & Vicia oroboides Wulfen & 2 & $\mathrm{H}$ & & \\
\hline \multirow{2}{*}{ Fagaceae } & Fagus sylvatica L. & 8 & $\mathrm{P}$ & & \\
\hline & Quercus petraea (Matt.) Liebl. & 8 & $\mathrm{P}$ & & \\
\hline \multirow[t]{2}{*}{ Fumariaceae } & Corydalis bulbosa (L.) DC. & 9 & G & & \\
\hline & Geranium pusillum Burm. f. & 8 & $\mathrm{~T}$ & & \\
\hline Geraniaceae & Geranium robertianum L. & 11 & $\mathrm{~T}$ & & \\
\hline Grossulariaceae & Ribes rubrum L. & 12 & $P$ & & \\
\hline \multirow[t]{5}{*}{ Hidrangeaceae } & Deutzia scabra Thunb. & 12 & $\mathrm{P}$ & & \\
\hline & Ajuga reptans L. & 9 & $\mathrm{H}$ & & \\
\hline & Glechoma hederacea L. & 10 & $\mathrm{H}$ & & \\
\hline & Lamium galeobdolon (L.) L. & 9 & $\mathrm{H}$ & & \\
\hline & Lamium maculatum (L.) L. & 9 & $\mathrm{H}$ & & \\
\hline \multirow[t]{5}{*}{ Lamiaceae } & Lamium orvala L. & 2 & $\mathrm{H}$ & & \\
\hline & Lamium purpureum L. & 9 & $\mathrm{~T}$ & & \\
\hline & Melissa officinalis L. & 1 & $\mathrm{H}$ & & \\
\hline & Prunella vulgaris L. & 11 & $\mathrm{H}$ & & \\
\hline & Stachys sylvatica L. & 9 & $\mathrm{H}$ & & \\
\hline
\end{tabular}




\begin{tabular}{|c|c|c|c|c|c|}
\hline Family & Taxon & $\begin{array}{l}\text { 0 } \\
\frac{0}{2} \\
\frac{1}{0} \\
\frac{1}{0}\end{array}$ & 혼 & 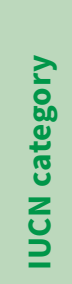 & 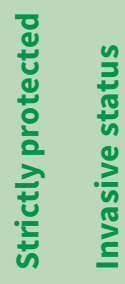 \\
\hline \multirow[t]{2}{*}{ Loranthaceae } & Loranthus europaeus Jacq. & 9 & $P$ & & \\
\hline & Hibiscus syriacus L. & 12 & $\mathrm{P}$ & & \\
\hline Malvaceae & Malva sylvestris L. & 11 & $\mathrm{H}$ & & \\
\hline \multirow{3}{*}{ Moraceae } & Ficus carica L. & 1 & $\mathrm{P}$ & & \\
\hline & Morus alba L. & 12 & $\mathrm{P}$ & & \\
\hline & Forsythia sp. & 12 & $P$ & & \\
\hline \multirow{3}{*}{ Oleaceae } & Fraxinus ornus L. & 3 & $\mathrm{P}$ & & \\
\hline & Ligustrum vulgare L. & 7 & $\mathrm{P}$ & & \\
\hline & Syringa vulgaris $\mathrm{L}$. & 12 & $\mathrm{P}$ & & \\
\hline Onagraceae & Circaea lutetiana L. & 11 & $\mathrm{H}$ & & \\
\hline Oxalidaceae & Oxalis acetosella L. & 11 & $\mathrm{H}$ & & \\
\hline \multirow[t]{2}{*}{ Papaveraceae } & Chelidonium majus L. & 11 & $\mathrm{H}$ & & \\
\hline & Plantago lanceolata L. & 11 & $\mathrm{H}$ & & \\
\hline \multirow[t]{2}{*}{ Plantaginaceae } & Plantago major L. & 11 & $\mathrm{H}$ & & \\
\hline & Plantago media L. & 9 & $\mathrm{H}$ & & \\
\hline \multirow[t]{4}{*}{ Platanaceae } & Platanus orientalis L. & 12 & $P$ & & \\
\hline & Fallopia baldschuanica (Regel) Holub & 12 & $\mathrm{P}$ & & \\
\hline & Fallopia convolvulus (L.) Á. Löve & 11 & $\mathrm{~T}$ & & \\
\hline & Polygonum aviculare L. & 11 & $\mathrm{~T}$ & & \\
\hline \multirow[t]{5}{*}{ Polygonaceae } & Reynoutria $\mathrm{x}$ bohemica Chrtek et Chrtková & 12 & G & & + \\
\hline & Rumex acetosa $\mathrm{L}$. & 11 & $\mathrm{H}$ & & \\
\hline & Rumex crispus L. & 11 & $\mathrm{H}$ & & \\
\hline & Rumex obtusifolius L. & 11 & $\mathrm{H}$ & & \\
\hline & Cyclamen purpurascens Mill. & 3 & G & NT & \\
\hline \multirow[t]{4}{*}{ Primulaceae } & Lysimachia nummularia L. & 8 & $\mathrm{H}$ & & \\
\hline & Primula vulgaris Huds. & 3 & $\mathrm{H}$ & & \\
\hline & Anemone nemorosa L. & 11 & G & & \\
\hline & Aquilegia vulgaris L. & 9 & $\mathrm{H}$ & & \\
\hline \multirow{4}{*}{ Ranunculaceae } & Clematis vitalba $\mathrm{L}$. & 8 & $\mathrm{P}$ & & \\
\hline & Ranunculus acris L. & 11 & $\mathrm{H}$ & & \\
\hline & Ranunculus ficaria $\mathrm{L}$. & 8 & G & & \\
\hline & Ranunculus lanuginosus L. & 7 & $\mathrm{H}$ & & \\
\hline
\end{tabular}




\begin{tabular}{|c|c|c|c|c|c|c|}
\hline \multirow[t]{10}{*}{ Family } & Taxon & $\begin{array}{l}\text { ํㅜ } \\
\text { 은 } \\
\text { ํㅜㄴ }\end{array}$ & 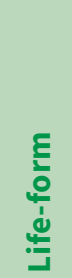 & 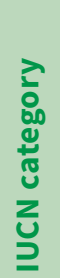 & 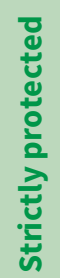 & 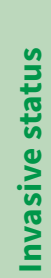 \\
\hline & Chaenomeles japonica (Thunb.) Spach & 12 & $P$ & & & \\
\hline & Crataegus laevigata (Poir.) DC. & 8 & $\mathrm{P}$ & & & \\
\hline & Duchesnea indica (Andrews) Focke & 12 & $\mathrm{H}$ & & & + \\
\hline & Fragaria moschata Weston & 7 & $\mathrm{H}$ & & & \\
\hline & Fragaria vesca L. & 11 & $\mathrm{H}$ & & & \\
\hline & Geum urbanum L. & 11 & $\mathrm{H}$ & & & \\
\hline & Kerria japonica (L.) DC. & 12 & $\mathrm{P}$ & & & \\
\hline & Potentilla micrantha DC. & 3 & $\mathrm{H}$ & & & \\
\hline & Potentilla reptans $\mathrm{L}$. & 1 & $\mathrm{H}$ & & & \\
\hline \multirow[t]{11}{*}{ Rosaceae } & Prunus armeniaca L. & 12 & $\mathrm{P}$ & & & \\
\hline & Prunus avium (L.) L. & 9 & $\mathrm{P}$ & & & \\
\hline & Prunus domestica L. & 12 & $\mathrm{P}$ & & & \\
\hline & $\begin{array}{l}\text { Prunus domestica L. ssp. insititia (L.) Bonnier et } \\
\text { Layens }\end{array}$ & 12 & $P$ & & & \\
\hline & Prunus laurocerasus L. & 12 & $\mathrm{P}$ & & & \\
\hline & Prunus padus L. & 9 & $\mathrm{P}$ & & & \\
\hline & Rosa canina L. & 11 & $\mathrm{P}$ & & & \\
\hline & Rubus saxatilis L. & 10 & $\mathrm{H}$ & & & \\
\hline & Sorbus torminalis (L.) Crantz & 9 & $\mathrm{P}$ & & & \\
\hline & Galium aparine L. & 11 & $\mathrm{~T}$ & & & \\
\hline & Galium mollugo L. & 9 & $\mathrm{H}$ & & & \\
\hline \multirow{4}{*}{ Rubiaceae } & Galium odoratum (L.) Scop. & 9 & G & & & \\
\hline & Galium sylvaticum L. & 8 & G & & & \\
\hline & Populus alba L. & 9 & $P$ & & & \\
\hline & Populus x canadensis Moench & 12 & $P$ & & & \\
\hline \multirow{4}{*}{ Salicaceae } & Populus nigra var. italica Münchh. & 12 & $\mathrm{P}$ & & & \\
\hline & Salix alba L. & 9 & $\mathrm{P}$ & & & \\
\hline & Salix caprea L. & 9 & $\mathrm{P}$ & & & \\
\hline & Salix $\times$ salamonii (Carrière) Carrière & 12 & $\mathrm{P}$ & & & \\
\hline \multirow[t]{3}{*}{ Saxifragaceae } & Saxifraga tridactylites L. & 11 & $\mathrm{~T}$ & & & \\
\hline & Lathraea squamaria L. & 9 & G & & & \\
\hline & Veronica chamaedrys L. & 9 & $\mathrm{H}$ & & & \\
\hline \multirow{4}{*}{ Scrophulariaceae } & Veronica hederifolia L. & 9 & $\mathrm{~T}$ & & & \\
\hline & Veronica officinalis L. & 10 & $\mathrm{H}$ & & & \\
\hline & Veronica persica Poir. & 11 & $\mathrm{~T}$ & & & + \\
\hline & Veronica serpyllifolia L. & 11 & $\mathrm{H}$ & & & \\
\hline
\end{tabular}




\begin{tabular}{|c|c|c|c|c|c|c|}
\hline Family & Taxon & $\begin{array}{l}\text { ஃ } \\
\text { 은 } \\
\text { 은 }\end{array}$ & 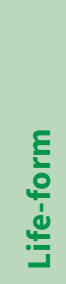 & 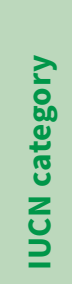 & 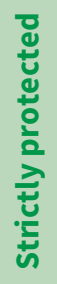 & 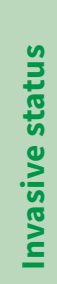 \\
\hline Simaroubaceae & Ailanthus altissima (Mill.) Swingle & 12 & $\mathrm{P}$ & & & + \\
\hline Solanaceae & Datura stramonium L. & 11 & $\mathrm{~T}$ & & & + \\
\hline Taxodiaceae & Cryptomeria japonica (L. f.) D. Don & 12 & $P$ & & & \\
\hline Thymelaeaceae & Daphne laureola L. & 3 & $\mathrm{P}$ & NT & & \\
\hline Tiliaceae & Tilia cordata Mill. & 8 & $\mathrm{P}$ & & & \\
\hline Ulmaceae & Ulmus glabra Huds. & 11 & $\mathrm{P}$ & & & \\
\hline Urticaceae & Parietaria officinalis L. & 3 & $\mathrm{H}$ & & & \\
\hline & Urtica dioica L. & 11 & $\mathrm{H}$ & & & \\
\hline \multirow{2}{*}{ Valerianaceae } & Valeriana officinalis L. & 9 & $\mathrm{H}$ & & & \\
\hline & Valerianella locusta (L.) Laterr. & 1 & $\mathrm{~T}$ & & & \\
\hline \multirow{4}{*}{ Violaceae } & Viola alba Besser & 3 & $\mathrm{H}$ & & & \\
\hline & Viola odorata L. & 8 & $\mathrm{H}$ & & & \\
\hline & Viola reichenbachiana Jord. ex Boreau & 9 & $\mathrm{H}$ & & & \\
\hline & Viola riviniana Rchb. & 8 & $\mathrm{H}$ & & & \\
\hline \multirow{2}{*}{ Vitaceae } & Parthenocissus quinquefolia (L.) Planchon & 12 & $\mathrm{P}$ & & & \\
\hline & Vitis vinifera $\mathrm{L}$. & 12 & $\mathrm{P}$ & & & \\
\hline
\end{tabular}

